\title{
POETRY
}

\section{Pitting cherries}

Previously published at www.cmaj.ca

My knife enters the flesh the hard pit stops the blade before it can reach my hand

cherry juice runs between my fingers discoloring my skin blood dripping into a stainless steel sink

\section{Wynne Morrison MD MBE}

Director, Fellowship Program in Critical Care Medicine

The Children's Hospital of Philadelphia

Philadelphia, USA

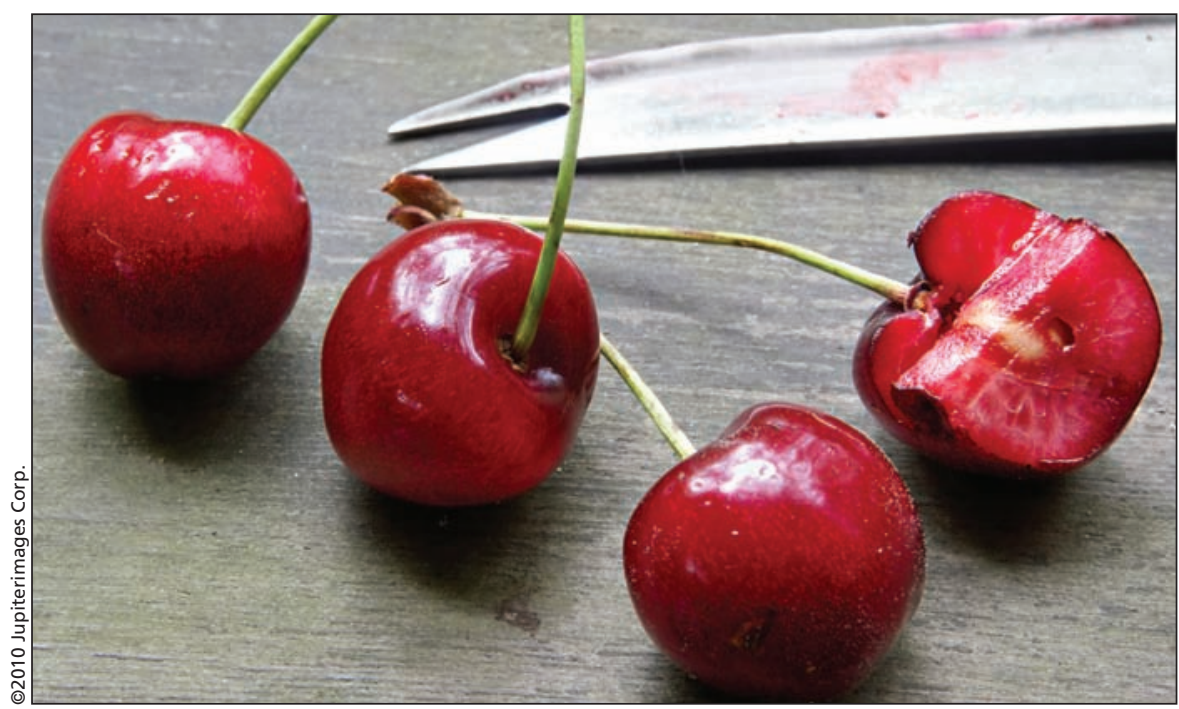

